\title{
APPROACH TO HOMELESSNESS VULNERABILITY AND THE IMPACT AS ONE HEALTH INITIATIVE
}

\author{
(Abordagem à vulnerabilidade de desabrigados e o impacto como iniciativa de \\ saúde única)
}

Mara Lucia Gravinatti ${ }^{1}$, Jorge Timenetsky ${ }^{2}$, Alexander Welker Biondo ${ }^{1 *}$

\footnotetext{
${ }_{1}^{1}$ Programa de Pós-graduação em Ciências Veterinárias, Universidade Federal do Paraná, Curitiba, Paraná, Brasil.

${ }^{2}$ Departamento de Microbiologia, Instituto de Ciências Biomédicas, Universidade de São Paulo, São Paulo, São Paulo, Brasil.
}

*Correspondence to: abiondo@ufpr.br

RESUMO: Pessoas em situação de rua têm sido consideradas um problema mundial na área da política pública e que demanda uma intervenção multidisciplinar com abordagem de assistência social e saúde. Algumas dessas pessoas em situação de rua têm interação próxima e de companhia com animais domésticos. Embora animais de companhia possam oferecer estabilidade emocional, podem contribuir para recusa no acolhimento humano e persistência nas ruas, como animais de companhia podem ser proibidos de adentrar em abrigos humanos. A presença de animais e a superexposição ambiental podem agravar coinfecções nestas populações vulneráveis. Por isso a importância de incluir o médico veterinário na rede multidisciplinar para garantir a saúde animal e reduzir as zoonoses e seus fatores de risco associados.

Palavras-chave: animais de companhia; pessoa em situação de rua; zoonoses

ABSTRACT: Homeless has been considered a worldwide public policy problem and may demand a multi-professional intervention with social assistance and health care approaches. Some of these homeless may have close and companion interactions with domestic animals in their environment. Although pets may provide emotional stability, may also contribute to human sheltering refusal and homeless persistence, as pets may not be allowed on most human shelters. Pet presence and environmental exposure may aggravate co-infections in such vulnerable population. Therefore, veterinarian inclusion in such network care frame has been crucial to insure animal health and reduce zoonosis and related risk factor.

Key Words: domestic animals, homeless; zoonosis

\section{INTRODUCTION}

Social abandonment has been a main cause of homeless, considered a worldwide public policy issue (NARENDORF et al., 2017, GAETZ et al., 2016). Although maybe difficult to measure how many people live on streets, previous studies have shown approximately 31,922 homeless $(0.06 \%)$ in Brazil (WWP, 2009) 549,928 (0.17\%) in the United States (NAEH, 2017) and $35,000(0.10 \%)$ in Canada (GAETZ, et.al, 2016). Homeless have been considered persons in vulnerability situation who need an interrelated approach with social, health and psychological care (DAVIES and ALLEN, 2017). 
Animal relinquishment to streets has also been a public health problem, mainly in underdeveloped or developing countries (ALBERTHSEN, et al., 2016). Numerous studies have attempted to establish the human-animal interactions including stray dogs, with frequent situation of individual exposure within the social network (SINGER, 1995), clearly demanding a public policy of homeless health care and their animals.

Vulnerability may be defined as a dynamic and multifactorial concept associated to incapability to confront environmental disasters (usually transient) or poverty (transient or permanent) (CHRYSTAL, et al., 2015). Homeless cases have generally been consequence of society unbalance due to exclusion process, fragility by relation breaking, disrespect and/or discrimination (JAHAN, 2017). Such heterogeneous group have reportedly shown extreme experiences with poverty, marginality, health threats, domestic violence, social and mental health problems (BRASIL, 2009, HQO, 2016), aggravated by mental hospital enclosure and patient discharge in the 1980s-1990s (ABDUL-HAMID, 2014).

The Brazilian public policy approach on homelessness have been based on social care and health (Table 1) to ensure the "minimal essential" determined by the federal constitution until establishment of specific programs with own budget and staff.

Primary health professionals have generally been the first contact with these individuals, due to drug abuse, risky sexual illness or pregnancy, mental health disorders, starvation, and increased contact risk with pests and dirt (WHO, 1978, NOEL, et al., 2015). An interdisciplinary approach have contributed to better understand emerging and reemerging illnesses (MWANGI, 2016) and the dimension of the health and social care services in the most vulnerable urban group due risk exposure.

Although dogs and cats have few recognized rights, the United Nations Educational, Scientific and Cultural Organization - UNESCO has declared that all animals are born equal to life and have the right of exist. Not surprisingly, the most important federal law of environmental crimes in Brazil has included the relinquishment as animal abuse (BRASIL, 1998). In addition to abandonment, the number of animal shelters in Brazil have been limited and the rescue and care of the animals mostly taken by independent protectors or small non-profit organizations.

Numerous studies aiming to measure and understand animal abandonment have fail to show a common pet pattern (more female or male, younger or old) (FATJÓ, et al., 2015, NEW, et al., 2000). However, common causes such as aggression toward people or animals, precarious animal health condition, animal characteristics, lifestyle and no apparent owner (SALMAN, 1998) have been consistently observed.

Since species distribution and density may be determined by the dynamics of survival to infectious diseases and environmental factors such as lack of food or running overs (BROWN, 1984), abandoned human beings or animals may stay on urban areas as an invisible group and under street availability of food and shelter. In fact, wandering population may be used as an indicator of environmental deterioration and epidemiological indicator (LERNER, 2015).

Homeless person and animal may be considered as a unit who need a network service for better approaching their situation (SINGER, 1995). The human-animal homeless interactions may provide emotional stability and selfesteem and motivation for both (SINGER, 
1995). Even so, this relationship may also contribute in some cases for persistence of homelessness on streets, since sanitary restrictions and regulations may forbid pets in homeless shelters (FERRIGNO, 2015).

Pet prohibition into human shelters seems to rely on potential risk and aggravation of human exposure to infectious agents, mainly due to the possibility of zoonosis transmission as leishmaniasis, spotted fever, toxoplasmosis, leptospirosis, among others. However, increase in morbidity of various illness as HIV or other sexually transmitted diseases, hepatitis B and C and tuberculosis has been considered as consequence of problems accessing and underutilization of medical care (CHRYSTAL, et al, 2015).

Among potential zoonoses transmitted by pets, toxoplasmosis has been considered an environmental disease (SMIELEWSKA-LOS, 2002) as well as leptospirosis, both which may be considered endemic in some urban areas resulting in exposure to infectious pathogens. Homeless may also be living within an environment with food remains, dirt and rodent's presence in their sleeping places (KANG, 2015), posting the human and other animal health conditions at risk.

Co-infections may also be opportunistically common in a vulnerable and immunosuppressed person, as for example the more susceptibility of HIV patients to tuberculosis (TB) infection (JOINT, 2000, CASPERMEYER, 2017), which may increase the risk of morbidity and mortality and be aggravated by drug or alcohol consumption (AUERSWALD, 2016).

Another zoonosis, tuberculosis among homeless has also been a public health challenge, with studies showing higher prevalence, co-infections, reluctance to treatment and consequently drug resistance (WORRELL et al., 2017). Such studies may lack comprehensive results due to exclusion or discharge of cases for their transient status and difficult logistical to understand homeless to homeless disease transmission. Pets under the same conditions may present the same epidemiological framework, as dogs may develop TB due to their close relationship with infected owners.

Such epidemiological scenario may place homeless human beings and stray pets in similar disease likelihood, sharing urban outdoors risk factors associated to pathogen infection and maintenance. In Brazil, the free-ofcharge governmental health network named "Unique Health System" has considered suspected or confirmed infectious diseases as compulsory notifications into the national system. Pets may be excellent sentinels for such diseases, since most infectious pathogens have zoonotic origin.

\begin{tabular}{|c|c|c|c|}
\hline $\begin{array}{l}\text { Area } \\
\text { Social } \\
\text { care }\end{array}$ & $\begin{array}{l}\text { Year } \\
1998\end{array}$ & \begin{tabular}{|l} 
Type \\
Federal \\
Constitution
\end{tabular} & $\begin{array}{l}\text { Content } \\
\text { "Minimal essential" }\end{array}$ \\
\hline $\begin{array}{l}\text { Social } \\
\text { care }\end{array}$ & 1993 & Law & $\mathrm{n}^{0}$ 8.742: National Law of Social Care (LOAS) \\
\hline $\begin{array}{l}\text { Social } \\
\text { care }\end{array}$ & 2004 & Program & National Program of Social Care (PNAS) \\
\hline $\begin{array}{l}\text { Social } \\
\text { care } \\
\text { Social } \\
\text { care }\end{array}$ & $\begin{array}{l}2005 \\
2006\end{array}$ & $\begin{array}{l}\text { Law } \\
\text { Decree }\end{array}$ & $\begin{array}{l}\mathrm{n}^{0} 11.258 \text { : Add homeless in program of social } \\
\text { care } \\
25^{\text {th }} \text { October: Inter-ministry proposital of } \\
\text { homeless social inclusion }\end{array}$ \\
\hline $\begin{array}{l}\text { Social } \\
\text { care }\end{array}$ & 2006 & Order & $\begin{array}{l}\mathrm{n}^{0} 381 \text { : Guarantee resources and create } \\
\text { reference centers }\end{array}$ \\
\hline $\begin{array}{l}\text { Social } \\
\text { care }\end{array}$ & 2008 & Law & $\begin{array}{l}\mathrm{n}^{0} 11.530 \text { and } 11.707 / 2008 \text { : National program } \\
\text { of public security }\end{array}$ \\
\hline $\begin{array}{l}\text { Social } \\
\text { care }\end{array}$ & 2009 & Resolution & $\begin{array}{l}\text { CNAS } n^{0} 109: \text { Typifies the social care } \\
\text { services }\end{array}$ \\
\hline Health & 2009 & Order & $\begin{array}{l}n^{0} 3.305: \text { Create a technical health committee } \\
\text { for homeless }\end{array}$ \\
\hline $\begin{array}{l}\text { Social } \\
\text { care }\end{array}$ & 2009 & Decree & $\mathrm{n}^{0} 7.503$ : National politics for homelessness \\
\hline $\begin{array}{l}\text { Social } \\
\text { care } \\
\text { Health }\end{array}$ & $\begin{array}{l}2010 \\
2010\end{array}$ & $\begin{array}{l}\text { Normative } \\
\text { Instruction } \\
\text { Decree }\end{array}$ & $\begin{array}{l}\text { SNAS/SNARC } n^{\circ} \text { 07: "CadÚnico" to provide } \\
\text { access in social care programs } \\
\mathrm{n}^{\circ} 7.179 \text { : National plan to stop crack and } \\
\text { another drugs }\end{array}$ \\
\hline $\begin{array}{l}\text { Social } \\
\text { care }\end{array}$ & 2011 & Law & $\mathrm{n}^{\circ}$ 12.435: Update LOAS \\
\hline Health & 2011 & Order & $\begin{array}{l}n^{0} 2.488 \text { : Create the National politics of } \\
\text { primary health }\end{array}$ \\
\hline Health & 2011 & Order & $\begin{array}{l}\mathrm{n}^{0} 122 \text { : Create 'Consultório na rua', to meet } \\
\text { homeless in local } \\
\mathrm{n}^{0} 3.088 \text { : Psychosocial attention network for } \\
\text { mental health }\end{array}$ \\
\hline $\begin{array}{l}\text { Social } \\
\text { care }\end{array}$ & 2013 & Resolution & $\begin{array}{l}\mathrm{n}^{0} \text { 09: Create 'Centro POP', a specific service } \\
\text { to homeless }\end{array}$ \\
\hline
\end{tabular}

\section{CONCLUSION}

Pets should be included on national census and their health considered as part of homeless health, as one of the strongest (or maybe last) bonds to society and its humanitarian 
values. Moreover, pets may be excellent animal, public and environmental sentinels in many situations, particularly in zoonotic diseases, making pet health monitoring as of crucial interest for the comprehensive One Health Initiative applied of homelessness.

\section{REFERENCES}

ABDUL-HAMID W.K.; BHUI, K. Psychiatry, homeless patients and welfare reforms: Historical links and chains. Internacional Journal of Social Psychiatric, v. 60, n. 1, p. 71-4, 2014.

ALBERTHSEN, C.; RAND, J.; MORTON, J., et al. Numbers and Characteristics of Cats Admitted to Royal Society for the Prevention of Cruelty to Animals (RSPCA) Shelters in Australia and Reasons for Surrender. Animals (Basel), v. 6, n. 3, 2016.

AUERSWALD, C.L.; LIN, J.S.; PARRIOTT, A. Six-year mortality in a street-recruited cohort of homeless youth in San Francisco, California. PeerJ, n. 4, p. 1 - 13, 2016.

BRASIL. Lei $\mathrm{n} \times \mathbf{9 . 6 0 5}$ de $\mathbf{1 2}$ de fevereiro de 1998. Dispõe sobre as sanções penais e administrativas derivadas de condutas e atividades lesivas ao meio ambiente, e dá outras providências. Available from: < http://www.planalto.gov.br/ccivil_03/leis/L 9605.htm>.

BRASIL. Decreto no 7.053 de 23 de dezembro de 2009. Institui a Política Nacional para a População em Situação de Rua e seu Comitê Intersetorial de Acompanhamento e Monitoramento, e dá outras providências. Available from: $<$ http://www.planalto.gov.br/ccivil 03/ at o2007-2010/2009/decreto/d7053. $\mathbf{h t m}>$.

BROWN, J.H. On the Relationship between Abundance and Distribution of Species. The American Naturalist, n. 2, 1984.
CASPERMEYER, J. HIV Coinfection Influences Natural Selection on Mycobacterium tuberculosis. Molecular Biology and Evolution, v. 34, n. 7, p. 1821 - 1822, 2017.

CHRYSTAL, J.G.; GLOVER, D.L.; YOUNG, A.S., et al. Experience of Primary Care among Homeless Individuals with Mental Health Conditions. PLoS ONE, v. 10, n. 2, 2015.

DAVIES, B.R.; ALLEN, N.B. Trauma and homelessness in youth: Psychopathology and intervention. Clinical Psychology Review, v. 54, p. 17-28, 2017.

FATJÓ, J.; BOWEN, J.; GARCÍA, E., et al. Epidemiology of Dog and Cat Abandonment in Spain (2008-2013). Animals (Basel), v. 5 , n. 2, p. 426-41, 2015.

FERRIGNO, S. Survey on the relationship between homeless people and the dog. Dog Behavior, n. 2, p. 18-24, 2015.

GAETZ, S.; DEJ, E.; RICHTER, T., ET al. Canadian Observatory on Homelessness Research Paper, 2016. Available from: http://homelesshub.ca/sites/default/files/S OHC16_final_200ct2016.pdf>.

HQO - Health Quality Ontario. Interventions to improve access to primary care for people who are homeless: a systematic review. Ontario Health Technology Assessment Series, v. 16, n. 9, p.1-50, 2016. Available from: http://www.hqontario.ca/Evidenceto-Improve-Care/Journal-Ontario-HealthTechnology-AssessmentSeries.

JAHAN, S. Human Development Report 2016: Human Development for Everyone. United Nations Development Programme, 2017. Available from: <http://hdr.undp.org/en/year/2016>.

JOINT - Joint Tuberculosis Committee of the British Thoracic Society. Control and prevention of tuberculosis in the United 
Kingdom: Code of Practice. Thorax, v. 55, n. 11, p. $887-901,2000$.

KANG, Y.M.; HAGIWARA, A.; UEMURA, $T$. Leptospirosis infection in a homeless patient in December in Tokyo: a case report. Journal of Medical Case Reports, v. 9, p. 198, 2015.

LERNER, H.; BERG, C. The concept of health in One Health and some practical implications for research and education: what is One Health? Infection Ecology and Epidemiology, n. 5, p. 25300, 2015. MWANGI, W.; DE FIGUEIREDO, P.; CRISCITIELLO, M.F. One Health: Addressing Global Challenges at the Nexus of Human, Animal, and Environmental Health. PLoS Pathogens, v. 12, n. 9, p. 455-60, 2016.

NAEH - National Alliance to end Homelessness, 2017. Available from: <http://www.endhomelessness.org >.

NARENDORF, S.C.; CROSS, M.B.; SANTA MARIA, D., et al. Relations between mental health diagnoses, mental health treatment, and substance use in homeless youth. Drug and Alcohol Dependence, v. 175, p. 1-8, 2017.

NEW, J.C.; KING, S.; SCARLETT, J.M., et al. Characteristics of Shelter-Relinquished Animals and Their Owners Compared With Animals and Their Owners in U.S. Pet-Owning Households. Journal of Applied Animal Welfare Science, v. 3, n. 3, p. 179-201, 2000.

NOEL, C.W.; FUNG, H., SRIVASTAVA, R., et al. Visual Impairment and Unmet Eye Care Needs Among Homeless Adults in a Canadian City. JAMA Ophthalmology, v. 133 , n. 4, p. 455-60, 2015.

SALMAN, M.D. Human and Animal Factors Related to the Relinquishment of Dogs and Cats in 12 Selected Animal Shelters in the United States. Journal of Applied Animal Welfare Science, n. 3, p. 207- 26, 1998.
SINGER, R.S.; HART, L.A.; ZASLOFF, R.L. Dilemmas associated with rehousing homeless people who have companion animals. Psychological reports, v. 77, n. 3, p. 851-57, 1995.

SMIELEWSKA-LOŚ, E.; PACOŃ, J. Toxoplasma gondii infection of cats in epizootiological and clinical aspects. Polish Journal of Veterinary Science, v. 5, n. 4, p. 227-30, 2002.

WHO - World Health Organization. Declaration of Alma-Ata: International Conference on Primary Health Care, 1978. Available from: <http://www.who.int/publications/almaata declaration_en.pdf>.

WORRELL, M.C.; KRAMER, M.; YAMIN, A., et al. Use of Activity Space in a Tuberculosis Outbreak: Bringing Homeless Persons Into Spatial Analyses. Open Forum Infectious Diseases, v. 4, n. 1, 2017.

WWP- World without poverty. Pesquisa Nacional sobre a População em Situação de rua, 2009. Available from: <http://www.wwp.org.br>. 